\title{
THE LOCAL-GLOBAL INNOVATION OF AN INDONESIAN TOEFL- LIKE GAME: A CULTURAL HYBRIDITY MODEL
}

\author{
Ekawati Marhaenny Dukut \\ English Department, Faculty of Language and Arts, Soegijapranata Catholic University, Indonesia \\ E-mail: ekawati@unika.ac.id
}

APA Citation: Dukut, E. M. (2019). The local-global innovation of an Indonesian TOEFL-like game: A cultural hybridity model. English Review: Journal of English Education, 7(2), 55-66. doi: 10.25134/erjee.v7i2.1605.

Abstract: The door to globalization for an Indonesian product is believed possible only when fulfilling some characteristics of other nation's culture. To ensure the global popularity of a product, therefore, there is a need of mixing the local with a global culture. The cultural hybridity strategy of mixing local-global scenes is evident in the invention of a TOEFL-like game software, which based itself on a mobile application for its platform. With the platform, the game becomes easily downloadable through Google Playstore. It is innovative as it accommodates the Generation Z's characteristics who are digital savvy. In the game, an animation is created for Listening section which takes in some forms of Javanese culture that are made hybrid with some American and Japanese ones. In finding out how successful the game is in fulfilling the needs of TOEFL-like game players, a Technology Accepted Model questionnaire is given to students from Indonesia and Japan. Japanese players, who are English Department students, were chosen on the assumption that they are more digital savvy. This article reports that the game is useful and beneficial in raising the English competence of both Indonesian and Japanese students. With the cultural hybridity strategy in creating the animation, the players agree that the game is a good model for learning about the English language in a fun and innovative way.

Keywords: cultural hybridity; digital media; Google Playstore mobile application; local-global innovation; popular culture.

\section{INTRODUCTION}

The Generation Z (Gen-Z) in Indonesia are claimed as those born in between the years 20002010 (Putri, 2016). The Gen-Z, according to the 2017 Nielsen Total Audience Report from the
U.S., is, however, born much earlier, i.e. from 1997. As the youngest generation in the planet, it is reported to make up as the largest population with the percentage of $26 \%$ as shown in Figure 1 (Sterling, 2017).

\section{GENERATIONAL COMPOSITION}

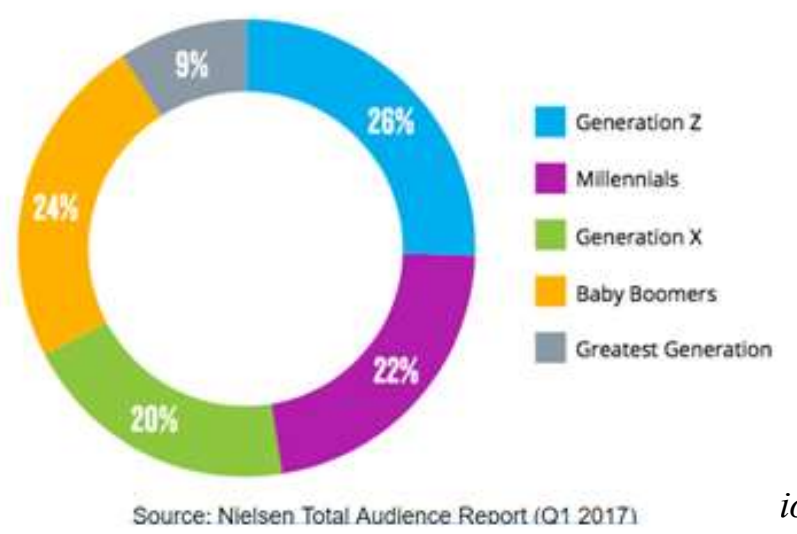

ions

As a generation who by the year of 2018 ranges from 8 to 21 years old, means that the Gen-Z are currently in primary school and up to a tertiary level of education. Acknowledging the Gen-Z as being the "click'n'go kids, the i-gen, or digital integrators, upagers, screenagers, and the global gen" as well as "double wrap generation" (Kompasiana, 2016) entails that the generation is characterized by the easiness of consuming ready-made packaged meals from fast food 
restaurants and also having a wide range of electronic gadgets as their main means of survival.

According to Seemiller and Grace (2016), if the previous Gen-Y or the Millennials had to be given lessons on how to make use of the computer or mobile phone to surf the internet to find information which is globally valid and reliable, the Gen- $Z$ are known to have an inborn quality with gadgets, hence are often labelled as Digital Natives or eBay babies as products are easily made available and paid online. The Gen$\mathrm{Z}$ as "information curators" often depend on their "Google Reflex" for the source of information (cited in Mohr \& Mohr (2017, p. 86) and enjoy instant rewards. They are also characterized as "loyal" to their friends, "thoughtful, compassionate, open-minded, responsible, entrepreneurial, excited," yet "not creative" and "fearful about the future" as they are "suffering from Fear of Missing Out (FOMO) anxiety" (Mohr \& Mohr, 2017, p. 87). One of the effects of having FOMO anxiety is that, in education, the Gen-Z still_needs an educator to help narrow resources for the completion of their coursework _(Buchanan \& Murray, 2018, p. 2). With this kind of condition and situation, as an educator, there is a challenge to equip the burning need of the Gen- $Z$ with educators that can innovate suitable education materials for them.

The sorts of materials Gen-Z like the most are electronic gadgets that are easily accessed around the globe. One such particular gadget is the popular mobile smartphone. As a popular culture product, the phone always has something to please its consumers by providing ways to satisfy its consumers, like being readily availabale at any place, yet constantly changing its features, in order to suit consumers' needs from all over the world. The internet facility that it has, not only functions as a notepad and media for communication through email or social media, such as Whatsapp, Twitter, Instagram, and Facebook; but it is also a gadget to save whatever information needs to be saved in the data storage facility.

Previous research from the Vision Critical announces that the Gen-Z are using 15.4 hours on the smartphone each week (Kleinshmit, 2015) to daily surf the web, make interactions with their social media friends, play online games and listen to live streaming music (Lubis, 2016). The small yet compact smartphone is, thus, a gadget that not only provides games for entertainment but also for serious games that can help students excel in their education.

Derakhshan and Khatir (2015) believe that games by nature are created to make players feel they have achieved something by playing something they enjoy doing. As implied above, games are not made purely for fun but also to support some aims of education. Consequently, serious educative games are created to entertain and educate student players, in order to have a positive attitude to learning as the games would increase the student player's motivation to do class work. Surati (2014, p. 9) informs that educative games have the mission to develop student players' problem-solving ability by taking advantage of their desire to learn and enthusiasm to play (Donmus, 2010). Surati (2014, p. 11) continues to explain that an educative game has the following SWOT analysis: it has a (1) Strength, because it can increase learning motivation, (2) Weakness, because not all schools have a computer lab or allow students to use game gadgets in class and some children still prefer to play games outside, (3) Opportunity, because it is played by all ages in the evening at home or at school to support learning activity, (4) Threat, because it is easily distracted with other gadgets, like interesting TV channels. In addition to frequent game playing, the Gen- $Z$ also frequently uses the internet that relies on the English language for global communication. This condition, therefore, forces the Gen-Z to master the English language.

Viewing through an education perspective, therefore, the researcher believes that an educative game material like the TOEFL (Test of English as a Foreign Language) exercise is relevant to produce as it is a gateway to further education or work. In Indonesia, the Ministry of Foreign Affairs sets a minimum of 550 PBT (Paper Based TOEFL) for employment. Although not dealing much with English during their daily conversation, the Ministry of StateOwned Enterprise, National Archives, and Bureaucracy Reformation of the Republic of Indonesia have also set a minimum of 450 PBT (Hamdani, 2018). According to Nurhayati and Nehe (2016, p. 10), a mastery in English is "extremely needed" because most Indonesian schools and employers believe the high TOEFL score shows how globally prepared a person is.

The TOEFL game to be discussed in this article is created by a team of Indonesian researchers from the English Department and the Information System of game Technology from 
Soegijapranata Catholic University of Semarang, Indonesia. In creating the test materials, the team adheres to the criteria of gaming that provides entertainment. Usually, students have to prepare themselves for the TOEFL by studying about the U.S. history, culture and academic life. Even though the questions are presented in multiple choice format like the TOEFL, the contents are not about U.S. history nor academic life. Instead, it is about a general knowledge that can be enjoyed by university as well as elementary and high school students. As head researcher, there is the intention from the beginning that the TOEFL game should help Indonesian Gen-Z youngsters to increase their English competence in an entertaining way with a topic that is not far from the local scene yet also give some knowledge about the global scene. Therefore, in designing the game, there is a deliberate purpose of inserting globalization and cultural hybridity concepts from the popular culture of gaming.

Paying attention that Gen-Z's favorite gadget is the smartphone, the educative TOEFL game is set to have the phone as its platform. As a product of popular culture, the contemporary gadget meets the needs of the Gen- $\mathrm{Z}$ people who want to communicate with each other from a distance. As a popular culture, the mass production of smartphones makes it available in the market with a reasonable price for people to buy. This becomes the reason why the phone is never off from the Gen-Z's fingertips. Purcell et al. (2010) exclaim that "along with the widespread embrace of mobile technology has come to the development of an apps culture", hence, a phone is no longer just a voice device but it is a multi-channel device that functions like a mobile mini-computer. Gen- $Z$ loves to use smartphones because alongside entertainment facilities, such as games and music, the informative apps are equipped with sending and receiving email, seeing maps and navigation, weather, news, and doing banking activities.

According to Pew Research Center that did a national survey to 1.917 cell phone users; as much as $82 \%$ of American adults are cell phone users. Out of the $82 \%$ of adults, there are $43 \%$ of them that have apps in their phones. Compared to the 30-49-year-olds, who are the $\mathrm{X}$ generation, the young adult users who are within the range of 18-29-year-olds have more app facilities. The average number of apps for the youngsters is 22, meanwhile for the adult is only 8 . The numbers prove that the Gen-Z really is a digital savvy generation.
In Indonesia, according to Statista.com (2018), in the year of 2017, there were 173.3 million phone users. This increased to 184 million in 2018 and is predicted to be even higher in 2019 as it will reach up to 193.4 million. As the fourth most populous country on earth, with $87 \%$ of households in Indonesia owning a mobile phone, it is an ideal place to popularize smartphone apps. A research on Mobile Games Trend in Indonesia 2017: Behavior of Mobile Games Usage (Nusaresearch, 2017) reports that 518 samples of 17-49 year-olds citizens enjoy their free time playing mobile games are reported to rely on Android platform. Only 3.7\% users prefer an iOS. Part of the reason for this occurrence is because the Apple-branded phone, which has the iOS, is a more expensive gadget to use. In using the gadget, $100 \%$ of the people taken as sample respond that they play games in their free time. Indonesians also devour over free or cheap games with $\mathrm{Rp} 3.000$ to $\mathrm{Rp} 15.000$, which is equivalent to a US $\$ 1$ per download. The preferred method of download is through Google Playstore and the purchase is by phone credit. Games preferred are those that have an interesting storyline $(69.1 \%)$, great graphics (68.5\%), many levels (67.07\%), less memory usage $(60.68 \%)$, is responsive $(55.6 \%)$, and others $(1.4 \%)$. This lets the researcher see that the TOEFL-like game app she and her team created and provided for free in Google Playstore as a model for learning English is a correct decision to do.

By using Google Playstore, the game is easily downloaded by anyone with an internet facility. Nalliveettil and Alenazi (2016, p. 264) informs that mobile phones with internet connectivity, however, give disadvantages, such as (1) almost replacing reference books that the library is no longer visited, (2) hinder students from activating cognitive skills like brainstorming and re-calling that are necessary for creativity, (3) make students believe that storing information in the mind is not important, and (4) affect classroom performance due to social networking chatting and browsing nonacademic websites. By comparison, the advantages of having mobile phones are, it is (1) helpful for vocabulary retention, (2) reliable to learn English, (3) dependable to understand English words and phrases, (4) a medium of communicating for Whatsapp messenger and email, and (5) helpful to enhance speaking, writing, translation, spelling and English 
language skills (Nalliveettil \& Alenazi, 2016, p. 265-268). These advantages are supported by deHaan (2011) who, after completing two projects, i.e. on game design and game magazine creation, finds that the games have improved his students' spoken and written English language skills. Language games are thus, not only a motivation for students to learn English in an entertaining way, but are also a media for authentic discussion about English.

The researcher sees that the TOEFL-like game should be popularly globalized. Becoming global means that there should be some Western elements in it because "globalization is tied up with [the] modernity" of the Western culture (Pieterse, 2006, p. 658). Further, Pieterse (2006) informs that, economically, globalization refers to the economic internationalization and capitalist market relations. Culturally, it focuses on global communications, where worldwide cultural standardization arises, such as in the American McDonaldization and CocaColonization. Sociologically, globalization concerns also with the increasing worldwide social densities. Thus, in a sociologist's mind, it is inferred that the USA's modernity is a key to globalization.

In devising the mobile smartphone game software, therefore, the concept of the local and global space becomes one of those important factors to ensure the continued attraction of the game played by anyone from the Gen- $Z$ community. For this reason, the researcher deliberately mixes Indonesian local culture with USA's culture, thus adhering to the concept of cultural hybridity. Just like the cultural hybridity of the Dutch culture that has influenced the Indonesian bestik; likewise, the American Kentucky Fried Chicken that became the Javanese Indonesian's kentuku fried chicken; the making of the TOEFL-like game has some local Javanese Indonesian culture that are made hybrid with the USA and other globalized countries' culture as a strategy of continually popularizing the game globally.

Reflecting on the above description, the problems raised in this study are formulated into the following research questions; 1) How successful is the game in the viewpoint of local Javanese Indonesian players and Japanese players as a representative of global players in increasing their English skills? and 2) What kinds of local and global aspects were evident in the game?

\section{METHOD}

In formulating a teaching learning model for English, the researcher has designed a two-year TOEFL-like game software project. The first year was to create the software on a PC (Personal Computer) platform (Dukut, 2018), whereby the second year was on a mobile smartphone. The choice of transforming the game onto a smartphone is due to the aim of having the game becomes more globally popular.

In the first year, the game players as participants of the research were $8^{\text {th }}$ grade Junior High School students in Semarang, Indonesia who has a computer lab with at least 20 computers. The three schools who agreed to have their students try out the game were from SMP Kebondalem (a Catholic-based school), SMP Eka Sakti (a Moslem-based school), and SMP Permata Bangsa (a school for foreign students). In the second year of the research, the targeted players were elevated for the $11^{\text {th }}$ grade of Senior High School and first-year university students of some Universities. The schools that agreed to have their students as participants were Chukyo High School in Japan, the English Department and Game Technology students of Soegijapranata Catholic Universitty in Indonesia, and the English Department students of Chukyo University, Japan.

The instrument to find out how successful the game is in providing an experience to do the game was a close-ended questionnaire with some open-ended questions as a follow-up. The questionnaire was based on a Technology Acceptance Model (TAM) theorized by Bargozzi et. al., which consist of statements dealing with (1) PEOU or perceived ease of use, which is the degree to which a person believes that the use of a particular system would be free of effort, (2) PU or perceived usefulness which is the degree to which a person believes that using a particular system would enhance job performance, (3) ATU or attitude toward using, which is a summary evaluation of a psychological object captured in such attribute dimensions as good-bad, harmful-beneficial, pleasant-unpleasant, and likable-dislikable, and (4) BI or behavioral intention, which is the degree to which a person has formulated conscious plans to perform or not perform some specified behavior.

The data collection procedure consists of an observation of the Gen-Z community. After mapping out that the generation is digital savvy, 
a TOEFL-like software is made to enhance English language competence. Once the game is paled by the participants, the questionnaire is distributed. Answers from the TAM modeled questionnaire using a Likered scale of 5 are then analyzed. The responses are categorized and interpreted as a finding for the research.

\section{RESULTS AND DISCUSSION}

\section{Tommy \& Pokina TOEFL-like app}

Games can be used to enhance a teachinglearning experience in English. The TOEFLLike mobile game application named Tommy \& Pokina is created and is downloadable from the Google Playstore with the aim of increasing as many Indonesian Gen-Z students' English ability through a fun yet serious educative game. There are four kinds of English skills being used in the game. Having an Integrated-Based TOEFL (IBT) as a model, the game offers thematic exercises which test players' Listening, Reading, Writing and Speaking ability. In the game, players are firstly, offered the choice of either playing with Tommy or Pokina. In the game Tommy, players are given an animation for the Listening section about a tomato character named Tommy who is a movie actor. Tommy shows that as a tomato, he benefits from his routine of using tomatoes as a facial mask, in addition to having it as the main menu for his diet because tomatoes have nutrients and vitamins that will keep him healthy. Details on the kinds of nutrients and vitamins tomatoes have are elaborated in the Reading section. A tomato pudding recipe is then shared as the topic for players to write about in the Writing section, and lastly for the Speaking section, players are given a poster on Tommy to describe in detail who he is, what he does, what kinds of nutrients and vitamins he has and what other factors help him become a popular movie actor.

By comparison, in the game Pokina, players are given an animation for the Listening section about a pakchoy character named Pokina who is a talented chef. Pokina shows that as a pakchoy, she benefits from her daily consumption of pakchoy that is often seen in the Indonesian meal: bakso and capjay. As a green vegetable, the pakchoy also has certain nutrients and vitamins that can support someone's health. Details on the kinds of nutrients and vitamins a pakchoy has are elaborated in the Reading section. A pakchoy ice cream recipe is then shared as the topic for players to write about in the Writing section, and lastly for the Speaking section, players are given a poster on Pokina to describe in detail who she is, what she does, what kinds of nutrients and vitamins she has and what other factors help her become a popular chef.

Understanding that a thematic game is much easier to do, thus, the game based its theme on the advantages of consuming tomatoes and pakchoy vegetables. The idea of using this theme is due to the researcher's concern that the Gen- $\mathrm{Z}$ prefer to consume some franchised USA food that is popularly shown in magazine advertisements and TV commercials, rather than locally home-made food.

In Indonesia, more Gen-Z consume Kentucky Fried Chicken, the MacDonald's Burger and the Pizza Hut products, which rely heavily on meat and carbohydrate and very little or even no vegetable salad nor vegetable soup as a compliment of the menu. With only seeing some tomato sauce on the Indonesian's plates rather than fresh cut tomatoes, or only one slice of lettuce and one ring of onion to put inside a King Burger product, it shows that the young Indonesian generation is lacking vegetable consumption. For this reason, in incorporating a cultural hybrid culture in the animation used for the TOEFL-like game, the researcher not only provided vocabulary and grammar exercises in the game to improve the student players' English skills, but also put in the idea that having a fresh cut tomato and pakchoy in the daily diet is importatnt. Actually, in the Pizza Hut restaurant, a consumer can enjoy a bowl of healthy green salad or a vegetable pizza to fulfill the vegetable diet someone needs. However, most Indonesian Gen-Z prefers to consume the American Favorite pizza, which only has beef and chicken meat on top of its cheesy pizza crust that is made from flour. This diet choice needs to be corrected, if Indonesian Gen-Z wants to grow with better health. This becomes the reason why the TOEFL-like game has a dual aim: (1) to improve the student players' English, and (2) to improve a healthier diet for the Gen-Z.

Unlike the real TOEFL where the PBT lasts for around 110-120 minutes, or the thematic based IBT which lasts for around 240 minutes, the Tommy \& Pokina TOEFL-like App game is created for only 45 minutes to play with. Although only 45 minutes, the apps offers exercises for Listening, Reading, Writing, and Speaking. Tommy \& Pokina TOEFL-like App game can be played for those in the Middle (Junior \& Senior High School) and Tertiary 
Schools (University level). Without the questions, the animated movie, which is within the Listening Exercise is applicable for Elementary School students to play with. The Reading section is also easy for Elementary School players because the concentration is on how to make use of the English tenses correctly. It is difficult for some players to do, however, because there are only a few seconds allocated to choose the right answer for the multiple choice questions provided. The Writing section is also timed and is limited to only 1000 words to narrate the process of cooking the tomato pudding or pakchoy ice cream menu. Depending on the vocabulary used in the writing, a teacher who evaluates the result can assign different marks for either Elementary, High School or University students of English. Finally, the Speaking section just gives out a poster with the vegetable cartoon character on a poster. With a limited time, the players are to describe in as much detail about what they see, hear and read about the character. As a teacher, he/she can decide on what kind of speech should receive a high score that is based on how complex the vocabulary is produced in the recorded speech.

\section{Indonesian vs Japanese viewpoints on the game}

One of the questions asked in this study is "How successful is the game in the viewpoint of local Indonesian players and Japanese players as a representative of global players in increasing

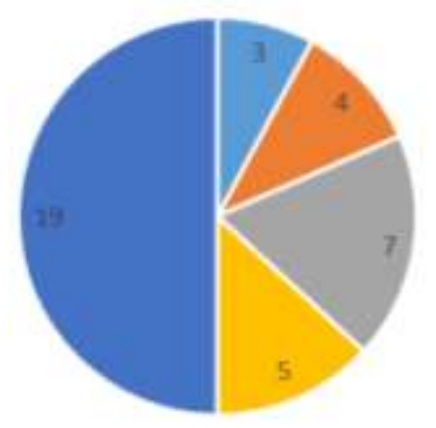

their English skills?" This question is answered by (1) taking into account the answers made in the game, and also (2) through the answers collected from the questionnaire.

Ever since the beginning, students have asked whether or not the answers they fill in the game would affect their regular school or course scores because they are given the explanation that it is far important to know that the game can be played well. It is assumed that students do not do the game seriously. It was then proven by the result of test takers from the English Department students in Soegijapranata Catholic University who were in the second semester. Out of 83 students that did the test, especially for the Listening and Reading test which had multiple choice questions, focused on their structure competency (see Chart 1).

As revealed in the result, only 3 students (7.89\%) scored an A, 4 students (10.53\%) scored a B, 7 students $(18.42 \%)$ scored a C, 5 students $(13.16 \%)$ scored a D, and 19 students $(50 \%)$ of them scored an E. The $50 \%$ of the students who were not doing the test seriously is most likely because they knew from the beginning that the recorded answers would not affect their school performance. It is revealed from the answers given in the questionnaire.

In the questionnaire, 24 close-ended statements were given with a 5 scale Likert score to reflect the respondents' opinions. The statements were based on TAM's guidelines.

Chart 1. Listening and Reading section test result

First, statements dealing with PEOU were reflected in the following statements with the results in percentage (see Table 1). With all of the highest percentage shown within the Agree column, it shows that the student players perceive the game as easy and entertaining to do, as well as easy to download when needed.

Second, statements dealing with PU were reflected in the following statements with the following results in percentage (see Table 2).

Table 1. PEOU percentage result

\begin{tabular}{clccccc}
\hline NO. & \multicolumn{1}{c}{ PEOU STATEMENTS } & SD & D & N & A & SA \\
\hline 2 & $\begin{array}{l}\text { The English language in the TOEFL-like game exercises } \\
\text { are easy to understand }\end{array}$ & 6.06 & 6.06 & 18.18 & 54.54 & 15.15 \\
\hline
\end{tabular}




\begin{tabular}{clccccc}
\hline 10 & $\begin{array}{l}\text { The time provided in each section is enough for me to } \\
\text { complete the exercises }\end{array}$ & 9.09 & 15.15 & 39.39 & 27.27 & 9.09 \\
\hline 13 & $\begin{array}{l}\text { The TOEFL Like App instructions in each section is } \\
\text { easy to follow }\end{array}$ & 3.03 & 12.12 & 27.27 & 36.36 & 21.21 \\
\hline 14 & $\begin{array}{l}\text { The button symbol for BACK, NEXT, RECORD, STOP } \\
\text { in the game application are easy to follow }\end{array}$ & 12.12 & 9.09 & 21.21 & 39.39 & 18.18 \\
\hline 15 & The navigation in the App is easy to follow & 9.09 & 3.03 & 33.33 & 36.36 & 18.18 \\
\hline 16 & $\begin{array}{l}\text { The multiple choice questions in the exercise are easy to } \\
\text { do }\end{array}$ & 9.09 & 0 & 18.18 & 66.66 & 6.06 \\
\hline 22 & $\begin{array}{l}\text { Searching TOEFL-Like App Tommy \& Pokina in } \\
\text { Google Playstore is easy }\end{array}$ & 3.03 & 9.09 & 24.24 & 48.48 & 15.15 \\
\hline
\end{tabular}

Table 2. PU percentage result

\begin{tabular}{clccccc}
\hline NO. & \multicolumn{1}{c}{ PU STATEMENTS } & SD & D & N & A & SA \\
\hline 1 & $\begin{array}{l}\text { Learning English with an animation is more interesting than } \\
\text { learning in a classroom with no digital media }\end{array}$ & 3.03 & 9.09 & 15.15 & 42.42 & 3.03 \\
\hline 5 & I learn about different culture in the animation & 6.06 & 9.09 & 33.33 & 36.36 & 15.15 \\
\hline 6 & $\begin{array}{l}\text { I learn more about the benefits of vegetables in the } \\
\text { animation of the listening section }\end{array}$ & 9.09 & 9.09 & 21.21 & 48.48 & 12.12 \\
\hline 7 & $\begin{array}{l}\text { I found new information about vegetable consumption in the } \\
\text { reading exercise }\end{array}$ & 9.09 & 9.09 & 27.27 & 33.33 & 21.21 \\
\hline 17 & The application works well & 6.06 & 24.24 & 18.18 & 45.45 & 6.06 \\
\hline 21 & $\begin{array}{l}\text { TOEFL Like App Tommy \& Pokina meets the needs of } \\
\text { learners having various learning styles }\end{array}$ & 6.06 & 3.03 & 24.24 & 57.57 & 9.09 \\
\hline
\end{tabular}

Similar to the result of PEOU, all of the statements receive a high percentage of agreement. This is gratifying to find, as it means that not only is the game helpful to elevate students' mastery in English through playing a TOEFL-like game, but the students also acknowledge that they learned something new about the culture of the West as well as East, in addition to the importance of consuming vegetables to keep them in good health. The aim of creating an educative game that gives benefits is successfully met. Third, attitude toward using (ATU) the game, by means whether it is regarded as good-bad, harmful-beneficial, pleasant-unpleasant, and likable-dislikable is shown the following statements with the results in percentage (see Table 3). It shows that most of the players agree that the game is beneficial. Proof of this is seen in statement numbers 3, 4, 9, 18 and 20 having the highest percentage in the Agree section.

Table 3. ATU percentage result

\begin{tabular}{|c|c|c|c|c|c|c|}
\hline NO. & ATU STATEMENTS & SD & $\mathrm{D}$ & $\mathrm{N}$ & $\mathrm{A}$ & SA \\
\hline 3 & $\begin{array}{l}\text { Learning English in class is more fun than learning through } \\
\text { an animated digital media }\end{array}$ & 6.06 & 12.12 & 39.39 & 36.36 & 6.06 \\
\hline 4 & $\begin{array}{l}\text { The culture-based characters in Tommy and Pokina } \\
\text { animation is interesting }\end{array}$ & 6.06 & 3.03 & 33.33 & 36.36 & 21.21 \\
\hline 8 & I like the vegetable recipe & 3.03 & 9.09 & 39.39 & 33.33 & 15.15 \\
\hline 9 & $\begin{array}{l}\text { I enjoy playing interactive digital media that challenges my } \\
\text { knowledge of English grammar }\end{array}$ & 6.06 & 9.09 & 18.18 & 54.54 & 12.12 \\
\hline 12 & I like doing the integrated based TOEFL Like App exercise & 3.03 & 6.06 & 42.42 & 36.36 & 12.12 \\
\hline 18 & The audio recording in the animation is clear & 12.12 & 9.09 & 30.3 & 42.42 & 6.06 \\
\hline 19 & The visual images are excellent and vivid & 3.03 & 15.15 & 39.39 & 33.33 & 9.09 \\
\hline 20 & $\begin{array}{l}\text { The color used in visualizing Tommy and Pokina is } \\
\text { appealing }\end{array}$ & 9.09 & 9.09 & 21.21 & 39.39 & 21.21 \\
\hline
\end{tabular}

Lastly, the behavioral intention (BI) component of TAM, in which a conscious plan of promoting or re-doing the game to enhance
English skills, is revealed through the responses for the statements below (see Table 4). 
Table 4. BI percentage result

\begin{tabular}{|c|c|c|c|c|c|c|}
\hline NO. & BI STATEMENTS & SD & $\mathrm{D}$ & $\mathrm{N}$ & $\mathrm{A}$ & SA \\
\hline 11 & $\begin{array}{l}\text { The speaking exercise encourages me to use my English } \\
\text { more actively }\end{array}$ & 6.06 & 3.03 & 30.3 & 54.54 & 6.06 \\
\hline 23 & $\begin{array}{l}\text { I will recommend my friend to use this application to learn } \\
\text { English }\end{array}$ & 3.03 & 9.09 & 45.45 & 33.33 & 9.09 \\
\hline 24 & $\begin{array}{l}\text { I will play this English language interactive learning game } \\
\text { again to get the best result }\end{array}$ & 3.03 & 16.16 & 30.3 & 33.33 & 15.15 \\
\hline
\end{tabular}

In the behavioral intention, although in one of the statement a high percentage is in neutrality, the other two statements receive a high percentage in the Agree section. This shows that the game will likely be enjoyed by others as it enhances the active use of English in speaking.

To give opportunities for the game testtakers to reflect back about the answers they have given through a Likert scale, four openended questions were asked. The questions not only confirmed TAM's questions on PU, ATU, and BI; but they also help the researcher have a better idea on what to do if there is a chance to modify the game.

The questions dealing with PU were questions number 2 and 3. First, in response to question 2, "What kind of feature can be added to make the TOEFL-Like App more interesting", the responses from the Indonesians were to: add music, add similar mini-games for iPhone users, add a Help button, add a Back button, modify the game into an adventure game where a multiplayer can come to play, add longer conversations, add more entertaining gestures, add more character interaction with the players, add questions with pictures, and use native speakers as the voice over. To see how popular, the game can be for people outside of Indonesia, the researcher also tested the game to Japanese students from Chukyo High School and Chukyo University in Nagoya. The Japanese students gave additional suggestions such as to: prolong the animation story, add more questions on the main idea of the story rather than on grammar, add a highlighter for the Reading section, more difficult questions are needed, and the game should give a bonus to correct answers given.
Second, in response to question 3 that also deals with PU, the question, "Which TOEFLLike section (Listening, Reading, Writing, Speaking) is the most beneficial to learn English? Why?" the responses of the most beneficial from Indonesian students (see Chart 2) were for: Listening $(37.83 \%)$, Reading (27.02\%), Speaking (24.32\%), and Writing $(0.10 \%)$.

Whereas, the Japanese (see Chart 3) regarded the most beneficial in Listening (50\%), Speaking (31.25\%), Reading $(0.10 \%)$, and Writing $(0 \%)$. The responses show that both Indonesian and Japanese students nowadays feel that Listening exercises need to be more facilitated, and becomes a logical explanation to why in the questionnaire, the students as players mostly agree that the animation feature in the TOEFL-like game is what makes the game interesting. The BI is shown through question 4 "If you could design an animation, what kind of animation do you want to make, so English learning is fun?" As an answer to the question, the Indonesians suggest: making an animation about animals, flowers, scrabble, vocabulary, word connect, grammar, landmark, artist, hangman, puzzle, daily lesson, and quiz up games.

The Japanese also have similar suggestions, but added that an interesting game should deal more with issues on family relationship, animals, sweets, Disney characters, translation, and classroom interaction between teacher and students. For the researcher, the answers all mean that students see the game as influencing them to be creative and imaginative, thereby, raising their English competency. 


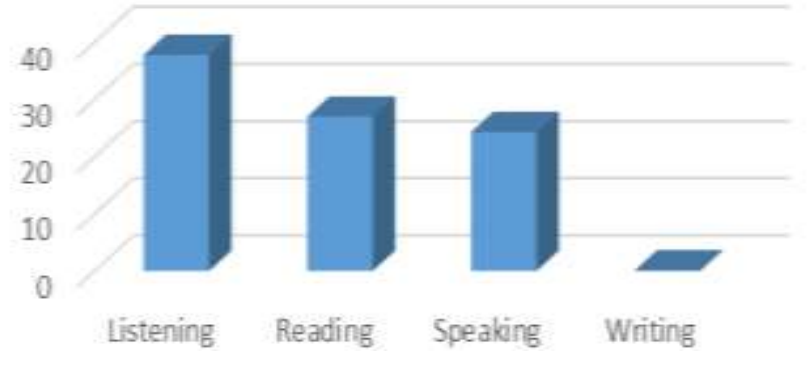

Chart 2. The TOEFL-like game app's benefits for Indonesian students

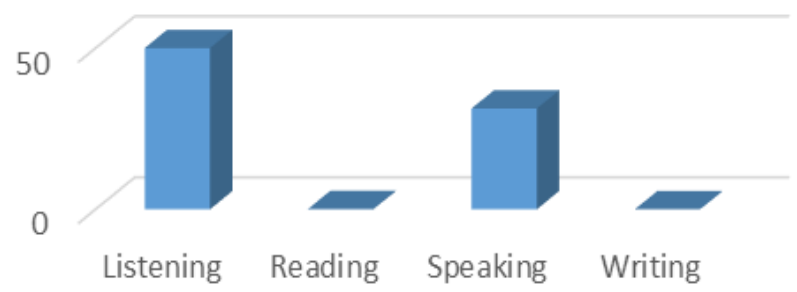

Chart 3. The TOEFL-like game app's benefits for Japanese students

Lastly, the ATU is reflected in question number 1, "In your opinion, what are the disadvantages of the digital media that makes use of animation?" Students reported that the disadvantages lie in some of the unclear picture and audio quality, the restricted time to do the test, the continual handling on the mobile phone, the incomplete feeling because there is no teacher intrusion, the non-auto orientation of watching the animation, the small writing area in the mobile phone, and the unfortunate game capability, which is only for the Android and not for the iPhone. Whereas, the advantages of the game were reported as helping students learn English better, giving a good learning method, making students more imaginative and creative, interesting and colorful characters in the animation were met, and facilitating beginner's need for studying TOEFL. They also reported that not many TOEFL games are available, so this game is beneficial for them because the game is easy to play with, and the animation was advantageous for them to help understand quickly with what they have heard.

The cultural hybridity and identity of the local and the global aspects of the game

In this study, another question has been formulated: What kinds of local and global aspects were evident in the game? The reason for this questioning is because the researcher understands the TOEFL as being USA made with USA facts and history inserted in the questions. With this kind of condition, the researcher assumes that not many Asians, unless already knowing about USA history and campus life and courses well, will have difficulty in understanding the topics and questions put forward in TOEFL tests. By the use of cultural hybridity in designing the animation, it is believed that the TOEFL can be enjoyed more by people, particularly Asians, such as the Indonesians and Japanese who became the main respondents of the study. The hybrid of the local to the global is believed to better attract the targeted test-takers' interest and enthusiasm in using English actively. Therefore, the researcher comes with the idea that there is a need to create a TOEFL-Like exercise, which will not only increase the test-takers English competence but also make the test-takers feel that taking an English competency test can be fun.

The insertion of the locality within the TOEFL, which has been accepted globally as the best way to test someone's English competence, is seen clearly in the animation created for Listening section. In the scene of Tommy, the tomato actor, he is given a Western suit and is seen showing his mastery of being an MC in the middle of a theater and exercising his muscles by going to a gym in order to show a global scene often shown up in popular media. This is made hybrid with the scene of Tommy being a tomato with a white towel on his head that would cleanse himself as though immersed in a local Japanese jacuzzi bathtub (see Figure 2). 


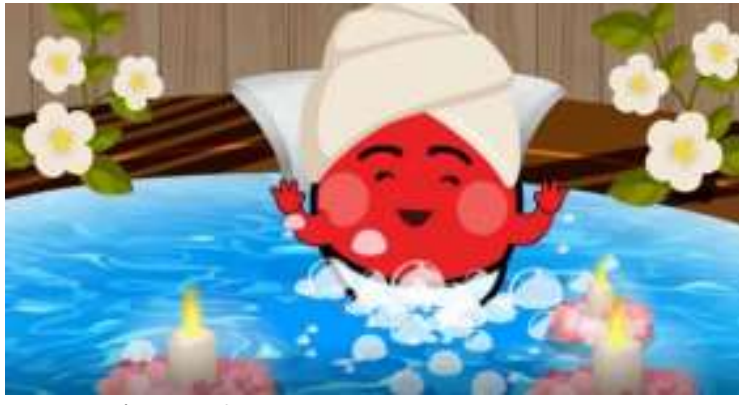

Figure 2. Tommy in a Jacuzzi

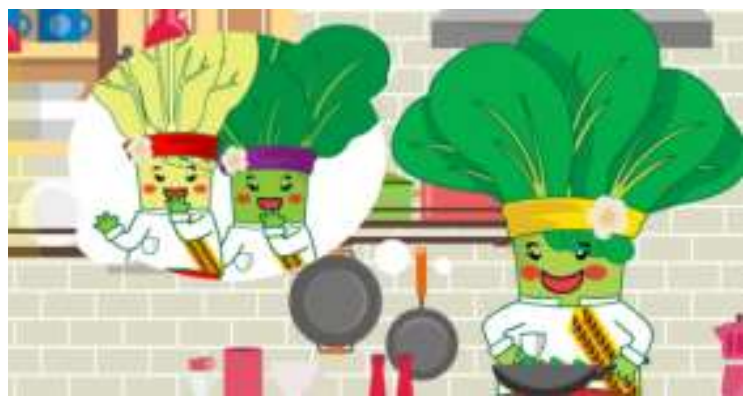

Figure 4. Pokina with her wok

Another scene is with Tommy still in his white towel but using the local Indonesian's way of using the tomatoes as a facial herb to clean his face. Indonesians believe that the tomatoes can make the face become brighter, so whatever dark blemishes were there can be reduced. In one of the answers of the Japanese test-takers, this particular scene (see Figure 3) is a new culture learned for them.

In the animation of Pokina the pakchoy chef, the global scene of the Western environment is having Pokina with a white uniform in a kitchen with an electric stove near a cupboard full of hanging kitchen utensils with plates and cutlery inside. This is made hybrid with the local Javanese Indonesian batik design on the white chef uniform. Another locality of the Asian's habit is also seen with Pokina preferring to use a Chinese wok (see Figure 4), or frying pan to stir fry her pakchoy vegetables with broccoli, cauliflower, and carrots. In another scene, the pakchoy is informed as to the vegetable used to consume with bakso, a meatball soup favorite for many Indonesians.

The scene of bakso sellers using a wheel cart pushed around Indonesian streets also adds onto the local scene. In the animation, the sound of spoons hitting the bakso bowl (see Figure 5) is also deliberately added to point out the Indonesian environment.

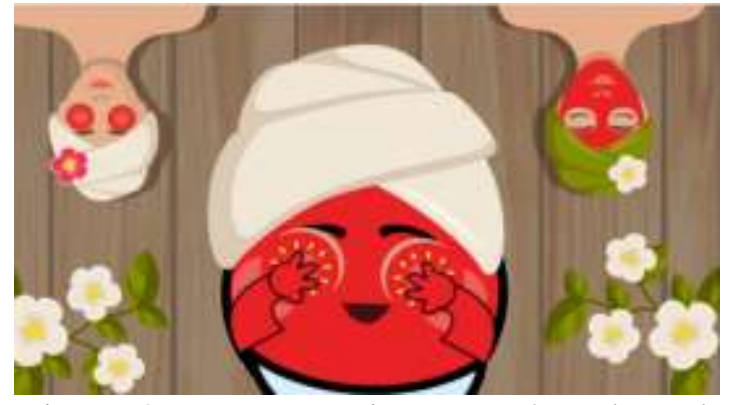

Figure 3. Tommy with tomato facial mask

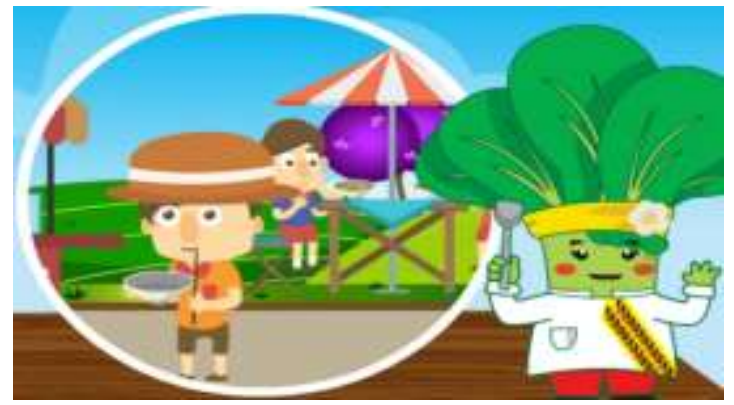

Figure 5. A bakso seller with his bowl

\section{CONCLUSION}

This article brings forth the result of a research done to enhance the English competence needed by English Department students in Indonesia and Japan. By the use of cultural hybridity which makes possible the mixture of local with global scenes, the researcher made a TOEFL-Like mobile game application that accommodates the local and global scenes of popular culture. This strategy is deliberately used in the design to popularize the local into a global culture, just like how the global culture gets into the local one. In making hybrid the local into the global or vice versa, each of the culture's identity is not troubled, instead they complement each other. The innovation of having the TOEFL as a game software that provides both entertainment and education has fulfilled the wish of the Gen-Z people, who are currently within their years of Elementary, Secondary and the first year of Tertiary Level. Using TAM as a guideline to a questionnaire that seeks to see how acceptable the Gen- $Z$ are towards the product, this article shows that the study has answered the question of how successful the game is in increasing students' English skill. As seen by the results shown in the previous Chart 2 and 3, both Indonesian and Japanese test-takers see the Tommy and Pokina TOEFL-Like Mobile Game App that can be downloaded from Google Playstore as being useful and beneficial. 
In answer to the second question about the local and global aspects, this article has also put forth the researcher's innovation of providing animated scenes and characters in the TOEFL game, which are touching the Indonesian and Japanese culture. This is different from the usual scenes used in TOEFL tests that would focus wholly on just the American culture. To conclude, therefore, the TOEFL game software as a product made by an Indonesian researcher does prove itself to be an appropriate model to increase students' English competency as the students who agreed to become test-takers have had the opportunity of exercising their English in a fun and creative way.

\section{ACKNOWLEDGEMENT}

The researcher is thankful to the Republic of Indonesia's Ministry of Technology, Research and Higher Education who has provided a grant via the 2018 PSNI scheme to realize the creation of Tommy \& Pokina TOEFL-Like Game Mobile App. The app is a product of the research she leads, which is entitled "Model Pembelajaran Bahasa Inggris Interaktif dengan Cergam Animasi Berbasis Budaya" (An Interactive English Language Learning Model Using a Culturally Based Animated Picturebooks). The app has become a model for a better interactive English teaching-learning environment that culturally hybrids a local into a global culture. Acknowledgement is also given to the $1 \mathrm{st}$ American Studies International Conference, where the initial paper draft was presented in 2526 October 2018, at Soegondo room, Faculty of Cultural Sciences, Gadjah Mada University, Yogyakarta, Indonesia.

\section{REFERENCES}

Buchanan, R., \& Murray, T. (2018). 'The internet is all around us': How children come to understand the internet. Digital Culture \& Education, 10(July), 1-21. Retrieved from http://www.digitalcultureandeducation.com/cms /wp-content/uploads/2018/07/Murray and Buchanan.pdf.

deHaan, J. (2011). Teaching and learning English through digital game projects. Digital Culture Education, 3(1), 46-55. Retrieved from: https://doi.org/10.1111/j.17477379.2003.tb00155.x.

Derakhshan, A., \& Khatir, E. D. (2015). The effects of using games on english vocabulary learning. Journal of Applied Linguistics and Language Research, 2(3), 39-47. Retrieved from http://www.jallr.com/index.php/JALLR/article/ view/40.

Donmus, V. (2010). The use of social networks in educational computer-game based foreign language learning. Procedia - Social and Behavioral Sciences, 9, 1497-1503. Retrieved from:

https://doi.org/10.1016/j.sbspro.2010.12.355.

Dukut, E. M. (2018). Popularizing Indonesian scenes through picturebooks and digital animation software: A world Englishes teaching idea. Asian Englishes. Retrieved from: https://doi.org/10.1080/13488678.2018.1459071

Hamdani, T. (2018). Lamar CPNS di instansi ini harus kuasai bahasa Inggris. Retrieved from: https://finance.detik.com/lowongan-kerja/d4222370/lamar-cpns-di-instansi-ini-haruskuasai-bahasa-inggris.

Kleinshmit, M. (2015). Generation Z characteristics: 5 infographics on the Gen $Z$ lifestyle. Retrieved from:

https://www.visioncritical.com/generation-zinfographics/.

Kompasiana. (2016). Gen Z, bonus demografi, dan masa depan Indonesia. Retrieved from: https://www.kompasiana.com/yudikurniawan/5 83fc7f9ba22bda00c8d8bf9/gen-z-bonusdemografi-dan-masa-depan-indonesia.

Lubis, M. (2016). Gen Z: Konsumen potensial masa depan. Retrieved from: https://www.nielsen.com/id/en/pressroom/2016/GEN-Z-KONSUMENPOTENSIAL-MASA-DEPAN.html.

Mohr, K. A. J., \& Mohr, E. S. (2017). Understanding Generation $\mathrm{Z}$ students to promote a contemporary learning environment, 1(1). doi: 10.15142/T3M05T

Nalliveettil, G. M., \& Alenazi, T. H. K. (2016). The impact of mobile phones on English language learning: Perceptions of EFL undergraduates. Journal of Language Teaching and Research, 7(2), 264-272. Retrieved from: https://doi.org/http://dx.doi.org/10.17507/jltr.07 02.04 .

Nurhayati, N., \& Nehe, B. M. (2016). An analysis of students' strategies in answering TOEFL. The Journal of English Language Studies, 01(01), 10-18. Retrieved from: http://jurnal.untirta.ac.id/index.php/JELS/article /view/682/535.

Nusaresearch. (2017). Mobile games trend in Indonesia 2017 behavior of mobile games usage, (August). Retrieved from: https://doi.org/10.1038/320124a0.

Pieterse, J. N. (2006). Globalization as hybridization. In M. G. Durham \& D. M. Kellner (Eds.), Media and cultural studies: Kyswore (pp. 658680). Cornwall: TJ International Ltd.

Purcell, K., Entner, R., \& Henderson, N. (2010). The rise of apps culture. Retrieved October 1, 2018, 
Ekawati Marhaenny Dukut

The local-global innovation of an Indonesian toefl-like game: A cultural hybridity model

from:

http://www.pewinternet.org/2010/09/14/therise-of-apps-culture/.

Putri, E. (2016). Generasi X, Y, Z, Alpha, Baby Boomers: Termasuk yang manakah kamu? Retrieved from: https://magazine.banananina.co.id/generasi-x-yz-alpha-baby-boomers-termasuk-yangmanakah-kamu/.

Seemiller, C., \& Grace, M. (2016). Generation Z goes to college. New York: Jossey-Bass.

Statista.com. (2018). Number of mobile phone users in Indonesia from 2013 to 2019 (in millions).
Retrieved September 30, 2018, from: https://www.statista.com/statistics/274659/forec ast-of-mobile-phone-users-in-indonesia/.

Sterling, G. (2017). Move over millennials, Gen-Z now the largest single population segment. Retrieved from: https://marketingland.com/move-millennialsgen-z-now-largest-single-population-segment219788.

Surati, S. (2014). Strategi pembangunan game edukasi berbasis desktop untuk anak usia 4-6 tahun. Journal Speed-Sentra Penelitian Edukasi Dan Engineering, 6(1), 8-17. 